\title{
Determination of Genetic Variation in Piper Species Using 4C Nuclear DNA and RAPD Markers
}

\author{
Budiguppe K. Chikkaswamy ${ }^{1}$, Rabin C. Paramanik ${ }^{1}$, Nagaraja Varadaraj ${ }^{2}$, \\ Achinto Paramanik ${ }^{1}$ Hyadala L. Ramesh ${ }^{3}$ Mallaiah Shivashankar ${ }^{4}$ \\ and Venkata R. Sivasam ${ }^{5}$ \\ ${ }^{1}$ PG Department of Biotechnology, R. K. Institute of Management \& Computer Science. No. 13, \\ Bellandur Gate, Sarjapura Main Road, Bangalore-560037. \\ ${ }^{2}$ Biotechnology Centre, Hulimavu, Department of Horticulture, Bangalore-560076. \\ ${ }^{3}$ Department of Biotechnology \& Applied Genetics, V. V. Pura Collage of Suience, Bangalore-560 004 \\ ${ }^{4}$ Department of Life Science, Bangalore University, Bangalore-560056. \\ ${ }^{5}$ Department of Botany, Bangalore Univerity, Bangalore-560056
}

Received January 22, 2007; accepted January 31, 2007

\begin{abstract}
Summary The present study utilized dominant markers such as Random Amplified Polymorphic DNA (RAPD) for the evaluation of relatedness among 6 Piper species were included in this study and to ensure such technique for claiming intellectual property right (IPR) by the plant breeder. Further, the study also aimed at estimation of the genetic relatedness of these 6 morpho-agronomically contrasting species. Six Piper species were screened using RAPD with decamer primer of arbitrary sequence. Out of 100 primers screened 12 were selected which gave clear and bright fragments. DNA banding patterns generated by RAPD were recorded as ' 1 ' for presence of the RAPD marker and ' 0 ' for absence. Genetic distance between these 6 species was calculated based on the RAPD data set as per Squared Euclidean distances. Based on the number of bands all the species were grouped into 3 clusters and the dendrogram revealed maximum similarity between $P$. betel and $P$. longum and also in between P. nigrum and P. mullesua species, altogether forming one cluster. The standardized method can identify any of the single hybrid or species tested.
\end{abstract}

Key words Piper, Nuclear DNA content RAPD, Genetic diversity

Piper is an important member of Piperceae, have a wide distribution in tropical and subtropical regions. The evergreen forest of the Western Ghats in South India is considered as the center of diversity of Piper nigrum and its close relatives. The genus includes important species like Piper nigrum; the black pepper, Piper longum and Piper betel, which are commonly used in the indigenous system of medicine. Among these, black pepper is one among the most widely used spices in the world. It is taxonomically a very difficult genus because of the greater range of variability and minute nature of flowers (Ravindran et al. 1992). However various attempts to classify the Piper species based on morphological, cytological studies by Sharma and Bhattacharya (1959) and chemical constituent data carried out by Sebastian and Sujatha (1996). But differentiation of species through morphological features is inefficient and inaccurate. The use of biochemical and genetic markers for identification of varieties offer a viable alternative method of Williams (1990). According to Lee et al. (1995) DNA based molecular markers are the most useful to detect the levels of genetic diversity in plant genome.

Until recently, several promising species released formally are characterized on the basis of morphological data, Piper content and yield potential. Worldwide demand on Piper necessitate work on conservation of Piper germplasm and their further genetic improvement. Therefore precise

*Corresponding author, e-mail: drchikkaswamy@rediffmail.com; robin_paramanik@yahoo.com 
characterization of promising species and determination of genetic variation among those are felt necessary. Until recently, several promising species released formally are characterized on the basis of morphological data, Piper content and yield potential. These characters differ under varying environmental condition thereby posing problem identification of species. Unlike morphological markers, cytological (chromosome numbers, nuclear DNA content) and molecular markers (RAPD, AFLP, ISSR etc.) are not prone to environmental influences and characterize the plants portraying the extent of genetic diversity among taxa (Bennett 1987, Bennett and Smith 1991, Waugh and Powell 1992, Chalmers et al. 1994, Das et al. 1998, Rodriguez et al. 1999, Das et al. 2001). Of the different markers, RAPD has been widely used in the last decade in species identification programme (Schnell et al. 1995) and in assessing genetic variations among different taxa at DNA level because of its cost effectiveness and simple operation without requiring prior knowledge of species DNA sequences (Williams et al. 1990, Frankel et al. 1995). RAPDs reveal similar patterns of genetic diversity when compared with other marker types and can be performed more rapidly than most other methods (Morell et al. 1995) and can provide vital information for the development of genetic sampling, conservation and improvement strategies (Waugh and Powell 1992, Chalmers et al. 1994). No report has been published so far either on the genetic characterization or on the extent of genetic variations existing among promising species of Piper using 4C DNA content and RAPD analysis. The present study deals with the in situ DNA estimation and RAPD analysis of 6 promising species of Piper to identify and evaluate extent of genetic variation existing among these.

As the efficiency of selection scheme or genetic analysis based on phenotype is a function of heritability of the trait, factors like environment, traits of multigenic and quantitative inheritance or partial and complete dominance often confound the expression of genetic traits. Many of these complications of a phenotype-based assay can be overcome through direct identification of species with DNA based diagnostic assay. For this reason DNA based genetic markers are being integrated into several plant systems under expected to play an important role in the future plant improvement programmes.

Polymerase chain reaction (PCR) technology as lead to the development of several novel genetic assays based on selective DNA amplification Krawetz (1989) and Innis et al. (1990). RAPD assay detects nucleotides sequence of polymorphism in DNA using only a single primer of arbitrary nucleotide sequence. The protocol is also relatively quick and easy to perform and uses fluorescence instead of radioactivity. Because the RAPD technique is amplification-based assay, only nanogram quantity of DNA is required. One of the strengths of these new assays is that they are more amenable to automation than conventional techniques. It is simple to perform and is preferable to experiment; their species of large number of individuals are to be determined at a few genetic loci.

\section{Materials and methods}

The present study selected leaf samples of 6 Piper species (P. nigrum, P. mullesua, P. longum, $P$. betel, $P$. retrofactum and $P$. chaba) were collected from the conservatory of Biotechnology Centre, Hulimavu, Department of Horticulture, Bangalore, Karnataka, India. Which may represent the wide variation prevalent in the genome. The recently matured leaves were collected and used for DNA extraction.

The basic DNA extraction protocol Dellaporta et al. (1983), was slightly modified following Porebski et al. (1997). $1 \mathrm{~g}$ of fresh leaf tissue was grinded using liquid nitrogen and then transferred to a centrifuge tube containing $20 \mathrm{ml}$ of extraction buffer (3\% CTAB, $100 \mathrm{mM}$ Tris, $20 \mathrm{mM}$ EDTA, 1.4 $\mathrm{M} \mathrm{NaCl}, 1 \% \mathrm{PVP}$ and $1 \% \mathrm{~B}$-mercaptoethanol) preheated to $60^{\circ} \mathrm{C}$ and maintained at this temperature for $1 \mathrm{~h}$ with intermittent shaking. The centrifuge tube was brought to room temperature and $6 \mathrm{ml}$ of chloroform and isoamyl alcohol $(24: 1)$ were added. The contents mixed well by inverting the tube gently $25-30$ times, then spun at 7,000 rpm for $15 \mathrm{~min}$. The supernatant was transferred to 
centrifuge tube and this clean-up step was repeated until a clear supernatant was obtained. Supernatant was kept overnight at $4^{\circ} \mathrm{C}$ to precipitate DNA by adding half a volume of $5 \mathrm{M} \mathrm{NaCl}$ and one volume of isopropanol. The DNA was pelleted by centrifuging at $10,000 \mathrm{rpm}$ for $20 \mathrm{~min}$ and the pellet was washed with $70 \%$ ethanol. The dried DNA pellet was resuspended in $300 \mu \mathrm{l}$ of TE (Tris EDTA) buffer. Contaminating RNA was removed by digestion with $10 \mu \mathrm{g}$ of RNase for $60 \mathrm{~min}$ at $37^{\circ} \mathrm{C}$. Proteins were removed by digestion with $25 \mu \mathrm{g}$ of Proteinase-K. The DNA was further purified by extracting twice with an equal volume of phenol followed by an equal volume of phenol : Chloroform $(1: 1)$ and finally with an equal volume of chloroform. The DNA was precipitated by the addition of one volume of isopropanol and spun at 5,000 rpm for $5 \mathrm{~min}$, the final pellet was dissolved in $300 \mu \mathrm{lTE}$. The DNA concentration was determined using UV-Visible spectrophotometer at $260 \mathrm{~nm}$ and $280 \mathrm{~nm}$ and the quality verified by electrophoresis on a $0.8 \%$ agarose gel and diluted to a uniform concentration of $5 \mathrm{ng} / \mu 1$ for RAPD analysis.

For Feulgen cytophotometric estimation of 4C DNA, 10 fixed root tips from each species were hydrolyzed in $1 \mathrm{~N} \mathrm{HCL}$ for $12 \mathrm{~min}$ at $60^{\circ} \mathrm{C}$, washed in distilled water and stained in Schiff's reagent for $2 \mathrm{~h}$ at $14^{\circ} \mathrm{C}$; each root tip squash was prepared in $75 \%$ acetic acid. Ten scorings were made from each slide and 4C DNA was estimated from metaphase chromosomes using NIKON Opitiphot microscope with microspectophotometer following the method of Sharma and Sharma (1980) with monochromatic light at $550 \mathrm{~nm}$. In situ DNA values were obtained on the basis of optical densities which were converted to picograms (pg) by using Van’t Hof's (1965) 4C nuclear DNA value (67.1 pg) for Allium cepa as standard species n-53 of Allium cepa was used in our experiment. ANOVA were performed among the nuclear DNA values to find out the differences at the species level.

\section{DNA amplification}

The basic protocol reported by Williams et al. (1990) for PCR was followed with slight modifications. A single decamer of arbitrary sequence was used in each PCR reaction. With the PCR reaction conditions optimized, informative and reproducible fingerprint profiles were carried out in $25 \mu \mathrm{l}$ reaction mixture containing template DNA (25 ng), 10 pmol of primer (Operon technologies USA, Inc.), $2.5 \mathrm{mM} \mathrm{MgCl}_{2}, 50 \mathrm{mM} \mathrm{KCl}, 10 \mathrm{mM}$ Tris- $\mathrm{HCl}$ and $0.1 \%$ Triton X-100. One unit of Taq DNA polymerase (Bangalore Genie) and $250 \mu \mathrm{M}$ of each dNTPs (Bangalore Genie). Amplification was performed in a thermal cycler (Eppendorf, Master cycler) for 42 cycles after an initial denaturation at $94^{\circ} \mathrm{C}$ for $5 \mathrm{~min}$. In each cycle, denaturation for $1 \mathrm{~min}$ at $94^{\circ} \mathrm{C}$, annealing for $1 \mathrm{~min}$ at $33^{\circ} \mathrm{C}$ and extension for $2 \mathrm{~min}$ at $72^{\circ} \mathrm{C}$ was programmed with a final extension step at $72^{\circ} \mathrm{C}$ for $8 \mathrm{~min}$ after the 40 cycle.

\section{DNA electrophoresis}

Amplified DNA fragments were separated out on 1.2\% agarose gel stained with ethidium bromide. Running buffer containing Tris-buffer, Acetic acid and EDTA (pH 8.0) was used for electrophoresis and for preparing gels. Wells were loaded with $25 \mu \mathrm{l}$ reaction volume and $5 \mu \mathrm{l}$ of loading buffer (Sucrose, Bromophenol blue and Xylene cyanol) together. Electrophoresis was conducted at 45 volts for $3 \mathrm{~h}$ and the gel photographed under UV light using gel dock system (Herolab).

\section{Statistical analysis}

Binary coding was used to score gel and each band of primer was scored of 6 species and 12 primers with 100 to 1000 base pairs Marker level pair wise squared Euclidean species was calculated and utilizing these distances, species were clustered following Wards method. The segregation of species was also assessed through principle component analysis, the Statistica version 5.0 a computer application was used to generate dendrogram using squared Euclidean distance and Wards method. 


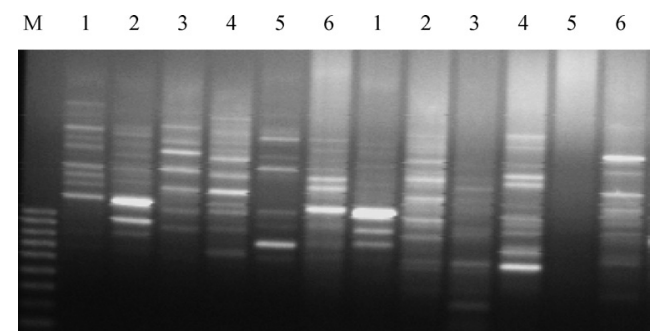

Fig. 1. Gel profile of Piper species (P. nigrum, P. mullesua, $P$. longum, $P$. betel, $P$. retrofactum and $P$. chaba amplified with selected primers like OPA 1-6 and OPD 1-6.

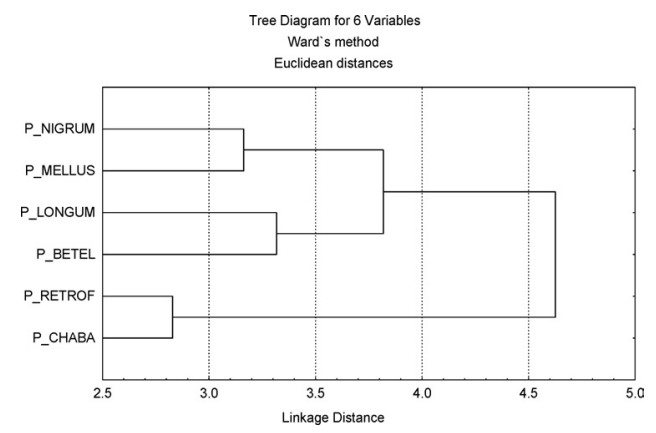

Fig. 2. Tree Diagram/Dendrogram depicting the genetic relationship of 6 Piper species.

Table 1. 4C nuclear DNA content in six piper species. (P. nigrum, P. mullesua, P. longum, P. betel, P. retrofactum and P. chaba)

\begin{tabular}{lcccc}
\hline \hline Species of Piper & $\begin{array}{c}\text { 4C nuclear } \\
\text { DNA content } \\
(\mathrm{pg})\end{array}$ & $\begin{array}{c}\text { Number of } \\
\text { polymorphic bands } \\
\text { (OPA 1-6) }\end{array}$ & $\begin{array}{c}\text { Number of } \\
\text { polymorphic bands } \\
\text { (OPD 1-6) }\end{array}$ & $\begin{array}{c}\text { \% of } \\
\text { polymorphic } \\
\text { bands }\end{array}$ \\
\hline P. nigrum & $8.74 \pm 0.04$ & 09 & 09 & 18.36 \\
P. mullesua & $8.58 \pm 0.06$ & 09 & 11 & 20.40 \\
P. longum & $7.31 \pm 0.05$ & 07 & 06 & 13.26 \\
P. betel & $6.81 \pm 0.05$ & 13 & 11 & 24.48 \\
P. retrofactum & $7.57 \pm 0.05$ & 06 & 00 & 06.12 \\
P. chaba & $4.20 \pm 0.06$ & 09 & 08 & 17.34 \\
\hline
\end{tabular}

\section{Results}

The yield and quality of DNA extracted by following the procedure described earlier was 10-25 ng per $\mu$ l for every gram of leaf sample. The DNA obtained was amplifiable and of high quality. Spectrophotometer reading of $1.7-1.8(260 \mathrm{~nm} / 280 \mathrm{~nm})$ confirmed the quality of DNA.DNA isolated from $500 \mathrm{mg}$ leaf tissue using $20 \mathrm{ml}$ extraction buffer yielded good quality, high molecular weight DNA (above $50 \mathrm{~kb}$ ). The quality of the DNA was also confirmed by gel electrophoresis.

In this study, 100 Operon random ten-base long, single stranded primers (OPA 1-6 and OPD with 12 primers in each group) were screened using the Piper species, which on an average gave nine bands. The selected 12 primers were used for the screening of species, in which all the bands obtained were either monomorphic/polymorphic and were considered for the precise calculation of genetic diversity.

The basic protocol described elsewhere for PCR was optimized for high quality amplification and intense repeatable banding patterns. However, a reduction in the amplification of fainter bands was noticed with large changes in template DNA concentrations, while too much DNA produced a smear effect, which emphasized the importance of quantification of the DNA for clear amplification.

A representative of the PCR amplification product of 6 species is shown in Fig. 1 which yielded sufficient polymorphisms to distinguish between species by Ward's method of analysis with Squared Euclidean distance gave dendrogram. Based on the number of bands all the species were grouped in three clusters (Fig. 2). The dendrogram revealed a maximum similarity between Piper nigrum and Piper longum species. Every single species/hybrid could be identified using these se- 
Table 2. Synthetic oligonucleotide OPA 1-6 and OPD $1-6$ used as primers for amplification of Piper DNA

\begin{tabular}{ccc}
\hline \hline Primer No. & Sequence & $\begin{array}{c}\text { Total no. of } \\
\text { fragments amplified }\end{array}$ \\
\hline OPA-01 & CAGGCCCTTC & 09 \\
OPA-02 & TGCCGAGCTG & 09 \\
OPA-03 & AGTCAGCCAC & 07 \\
OPA-04 & AATCGGGCTG & 13 \\
OPA-05 & AGGGGTCTTG & 06 \\
OPA-06 & GGTCCCTGAC & 09 \\
OPD-01 & ACCGCGAAGG & 09 \\
OPD-02 & GGACCCAACC & 11 \\
OPD-03 & GTCGCCGTCA & O6 \\
OPD-04 & TCTGGTGAGG & 11 \\
OPD-05 & TGAGCGGACA & 00 \\
OPD-06 & ACCTGAACGG & 08 \\
\hline
\end{tabular}

lected twelve primers.

Analysis of diversity based on PCR fragments amounted to saturating the genome. The analysis of 6 species of Piper suggested that diversity is moderate to high and has shown even differences also.

\section{Discussion}

\section{Diversification in DNA amount}

The 4C DNA values were reported for the first time in 6 species of piper significant differences of 4C DNA were recorded between species 8 having minimum $4.2 \mathrm{pg}$ to maximum 8.74 pg nuclear DNA content such intraspecific variations are in close agreement with the reports of other workers (Furuta et al. 1975,

Price et al. 1980, Das et al. 1998). The consistency in the DNA amount at the species level in the repeated experiment revealed the stable $4 \mathrm{C}$ DNA content in each species of piper. The DNA amount differed significantly and the difference in the DNA content depend on the repetitive DNA amount (Flavetl et al. 1977). The variability in the DNA content in different species might be attributed to the loss or addition of many repeats in the genomes through alteration in the micro- and macro-environment during evolution in the selection of new species (Price et al. 1980, Das et al. 1998). The variability of DNA amount could be attributed to loss or addition of highly repetitive DNA sequence rather than AT or GC rich sequences in a genome (Martel et al. 1997). Which is reached a certain level and got stabilized during micro-evolution and gradual selection. (Table 1).

\section{Clustering of species}

The squared Euclidean distances was calculated using the data on 6 piper species with 12 primers (OPA 01-06, OPD 01-06). Highest distance was observed between Piper nigrum and Piper chaba. The lowest distance was recorded between Piper retrof and Piper chaba.

The distance within species was least (2.84 units) and highest (4.6 units) and intermediate distance between (3.82 units). However this was in line with the results obtained in Wards genetic diversity calculations.

The dendrogram (Fig. 2) showed three distinct clusters namely 1. Piper nigrum and Piper mellus. Cluster 2 included Piper longum and Piper betel and cluster 3 showed Piper retrof and Piper chaba.

From the pattern of clustering, it was pertinent that RAPD technique was efficient in segregating species into different clusters. More significantly, the clustering had been largely successful in retaining the relationship between species as proposed by Schilling and Heiser (1981). In the light of current study at species level, it can be seen in the clustering pattern that the series were clearly distinguished in piper species. The association of the species observed in the present day was similar to the pattern observed by Sivloap and Solodenko (1998) and Khalid et al. (1999).

\section{Differential polymorphism of DNA}

The result presented in the present study demonstrated the utility of using RAPD markers to characterize genetic diversity among 6 promising species of piper. Differential polymorphism was noted in 6 species of piper showing variation in percentage of polymorphic bands from $24.48 \%$ to $06.12 \%$ using 12 primers of OPA 1-6 and OPD 1-6 (Table 1). The observed high proportion of 
polymorphic loci reveals profound variation among the piper species. Significant genetic variations by RAPD have also been reported in other species at species level (Colombo et al. 1998, Das et al. 1998, Huang et al. 2003). Wide genetic distances determined by Euclidean Wards genetic distance reveals relatively high genetic variation among 6 species. The considerable polymorphism detected in the present day also illustrated genetic diversity among piper species of the same origin as reported among coffee species (Sera et al. 2003). The observed differences among 6 piper species could be ascribed to the fluctuating micro and macro climatic conditions of habitat. Ward's analysis of RAPD data also reveals that all piper species belonging to the state of Karnataka are genetically closer. The greater sensitivity of RAPD obtained in the result to species diversity may be derived from rapid evolution of non-coding, repetitive DNA sequence detected by RAPDs. This hypothesis has been corroborated from (Plomion et al. 1995).

On comparison of 6 species in, it can be observed that though they differ largely in their, phenotypic expression, but the genetic difference as observed from DNA fingerprints was found to be low. The genetic variation as detected by RAPD analysis opens up the avenue for the proper identification and selection of the species that could be used for varietal identification and planning for future breeding programme.

RAPD analysis revealed a high degree of genetic diversity among the species examined in the study, which can contribute to the crop involvement. RAPD analysis can also be used for detecting gene flow between species. Furthermore, this technique is less restricting than other molecular technique RFLP (Restricted Fragment Length Polymorphism), as no hybridization and no use of radioisotopes is required, and it is therefore more convenient for use in research centers in developing countries.

Thus our results demonstrate that 4C DNA content and RAPD markers provide an effective tool for detection and evaluation of genetic variation existing among 6 promising species of pipers.

\section{References}

Bennett, M. D. 1987. Variation in genomic form in plants and its ecological implications. New Phytol. 106.- and Smith, J. B. 1991. Nuclear DNA amounts in angiosperms. Phil. Trans. Roy. Soc. Land. B334: 309-345.

Chalmers, K. Y., Newton, A. C., Waugh, R. and Powell, W. 1994. Evaluation of the extent of genetic variation in mahoganies (Meliaceae) using RAPD markers. Theor. Genet. 89: 504-508.

Colombo, C., Second, G., Valle, T. L. and Charrier, A. 1998. Genetic diversity character- ization of Cassava species (Manihot esculenta Crantz) 1. RAPD markers. Genet. Mol. Bio. 21: 69-84.

Dellaporta, S. L., Wood, J. and Hicks, J. B. 1983. A plant DNA minipreparation: Version II. Plant Molecular Biology Reporter, 1, 19-21.

Das, A. B., Rai, S. and Das, P. 1998. Karyotype analysis and 4C DNA content in some species of ginger (Zingiber officinale Rose.). Cytobios 93: 175-184.

Frankel, O. H., Brown, A. H. D. and Burdon. 1997. The Conservation of Plant Biodiversity. Cambridge University Press, Cambridge, U.K.

Flavell, R. B., Rimpau, J. and Smith, D. B. 1997. Repeated sequence DNA relationships in four cereal genomes. Chromosoma 63: 5-22.

Furuta, Y., Nishikawa, K. and Makino, T. 1975. Interspecific variation of nuclear DNA content in Aegilops squarrosa L. Jap. J. Genet. 50: 257-263.

Huang, H., Layne, D. R. and Kubisiak, T. L. 2003. Molecular characterization of cultivated Pawpaw (Asimina triloba) using RAPD markers. J. Amer. Soc. Hort. Sci. 128: 85-93.

Innis, M. A., Gelfand, D. H., Snisnky, J. J. and White, T. J. 1990. PCR protocols Ed 1. Academic Presee, San Diego, California, USA.

Khalid, S. A., Michel, T., Herve, S., Patrick, L., Yves, G., Francois, K. and Andre, B. 1990. Annex 1, Proc, 4th European Conf. On sunflower Biotech., Abstract of lectures 1. Species relationships based on genome organization in $\mathrm{He}$ lianthus. Helia 22: 181.

Krawetz, S. A. 1989. The polymerase chain reaction: Opportunities for agriculture. Agricultural and Biotechnological News Information, 1: 897-902.

Liston, A. and Arias, D. M. 1991. Phylogenetic and systematic inferences from chloroplast DNA and isozyme variation in 
Helianthus section. Helianthus (Asteraceae). Syst. Bot. 16: 50-76.

Lee, M. 1995. DNA markers and plant breeding program. Adv. Agron. 55: 265-344.

Martel, E., Denay, D., Siljakyakovlev, S., Brown, S. and Sarr, A. 1997. Genome size variation and basic chromosome number in pearl millet and fourteen related Pennisetum species. J. Heredity 88: 139-143.

Morell, M. K., Peakall, R., Appels, R., Preston, L. R. and Lloyd, H. L. 1995. DNA profiling technique for plant variety identification. Anus J. of Exp. Agri. 35: 807-819.

Plomion, C., Bahrman, N., Durel, C. E. and Malley, D. M. O. 1995. Genome mapping in pinus pinaster ( Maritime pine) using RAPD and protein marker. Heredity 74: 661-668.

Price, H. J., Bachman, K., Cihambers, K. L. and Riggs, J. 1980. Detection of interspecific variation in nuclear DNA content in Microseris douglasii. Bot. Gaz. 141: 195-198.

Porebski, S., Bailey, G. and Baum, B. R. 1997. Modification of a CTAB DNA extr action protocol for plants containing high polysaccharides and polyphenol components. Plant Molecular Biology Reporter, 15: 8-15.

Ravindran, P. N., Balakrishnan, R. and Nirmalbabu, K. 1992. Numerical taxonomy of South Indian Piper L. (Piperaceae) cluster analysis. Rheedea 2: 55-61.

Rodrigue, J. M., Berke, T., Engle, L. and Nienhuis, J. 1999. Variation among and within Capsicum species revealed by RAPD markers. Theo. Appl. Genet. 99: 147-156.

Schnell, R. J., Ronning, C. M. and Knight, R. J. 1995. Identification of species and validation of genetic relationship in Mangifera indica L. using RAPD. markers. Theor. Appl. Genet. 90: 269-274.

Sharma, A. K. \& Bhattacharya, N. K. 1959. Chromosome studies on two genera of family Piperaceae. Genetica, 29: 256-289.

— and Sharma, A. 1980. Chromosome Techniques: Theory and Practice. Third edition. Butterworths, London.

Sera, A. T., Ruas, P. M., Ruas, C. F., Diniz, L. E. C., Carvalho, V. P., Rampin, L., Ruas, E. A. and Silveira, S. R. 2003. Genetic polymorphism among 14 elite coffea Arabica L. species using RAPD markers associated with restriction digestion. Genet. Mol. Biol. 26: 59-64.

Schilling, E. E. and Heiser, C. B. 1981. Infrageneric classification of Helianthus (Compositae), Taxonomy 3: 393-403. Seiler, G. J. 1992. Utilization of wild sunflower for the improvement of cultivated sunflower. Field Crops Res. 30: 195-230.

Sivolap, Yu. M. and Solodenko, A. E. 1998. Inter and interspecies differentiation in the genus Helianthus by RAPD analysis. Helia 21: 9-18.

Sebastian, A. and Sujatha, V. S. 1996. Isoenzyme variation and species relationship in the genus piper. J. Tropical Agric. 34: 136-137.

Van't Hof, J. 1965. Relationships between mitotic cycle duration, S period duration and the average rate of DNA synthesis in the root meristem cells of several plants. Exp. Cell Res. 39: 48-58.

Wards. 1973. Analysis of gene diversity in subdivided populations. Proc. Natl. Acad. Sci., USA 70: 3321-3323. Riesberg, L., Beckstorm-Sternberg, S. M.

Williams, J. G. K., Kulelik, A. R., Livak, K. J., Rafalski, J. A. and Tingey, S. V. 1990. DNA polymorphisms amplified by arbitrary primers are useful as genetic markers. Nucleic Acids Research, 18: 6531-6535.

Welsh, J. and McClelland, M. 1990. Fingerpinting genomes using PCR with arbitrary primers. Nucleic Acids Research 18: $7213-7218$. 